\title{
Kajian Pengaruh Slotted dan Baffle Blocks pada Kolam Olak Roller Bucket Terhadap Peredam Energi
}

\section{Study of Slotted and Baffle Block Impact on Energy Dissipation in Roller Bucket Stilling Basin}

\author{
Jaji Abdurrosyid. Putri Dyah Pratiwi \\ Program Studi Teknik Sipil, Fakultas Teknik, Universitas Muhammadiyah Surakarta, \\ Jl. A. Yani Pabelan Kartasura Tromol Pos I Surakarta, 57102 Indonesia, \\ e-mail: jarrosyid@yahoo.com,putri.dyah277@gmail.com
}

\begin{abstract}
ABSTRAK
Beberapa upaya yang dilakukan manusia untuk mengalirkan air dari sungai ke sawah salah satunya dengan membangun bendung Akibat dari pembendungan, terjadi loncatan hidrolis di bagian hilir yang menyebabkan gerusan lokal. Hal ini terjadi apabila adanya perubahan jenis aliran superkritis menjadi subkritis. Guna mereduksi energi pada aliran, maka digunakan kolam olak tipe roller bucket dan baffle blocks. Gigi (slotted) pada kolam olak roller bucket memilik fungsi memecah aliran, dan fungsi baffle blocks sebagai penambah reduksi energi di hilir. Sehingga bentuk dari gigi dan baffle blocks berperan dalam reduksi energi aliran. Tujuan dari penelitian ini untuk mengetahui pengaruh bentuk gigi dan baffle blocks dalam mereduksi energi kaitanya dengan angka Reynolds dan Froude.

Penelitian dilakukan di Laboratorium Hidraulika Program Studi Teknik Sipil Fakultas Teknik UMS. Penelitian menggunakan open flume berukuran $0,3 \times 0,6 \times 10 \mathrm{~m}$ dengan kemiringan saluran 0,0058 . Menggunakan pelimpah tipe ogee dan kolam olak tipe roller bucket dengan gigi segitiga, trapezium, setengah lingkaran dan baffle blocks tipe cekung, V, dan balok (kubus). Penelitian dilakukan dengan 12 seri, masing-masing seri dilakukan lima tahap running dengan lima macam variasi debit, sehingga total running sebanyak 60 running. Setiap debitnya dilakukan pengujian panjang loncat air dan kehilangan energi.

Hasil penelitian menunjukan kolam olak roller bucket dengan gigi setengah lingkaran dan baffle blocks tipe cekung paling efektif menahan gaya tumbukan aliran, mereduksi turbulensi aliran, mereduksi panjang loncatan air, dan meredam energi. Hal tersebut dikarenakan garis singgung aliran pada polinom pangkat 2 mempunyai arah aliran yang memotong aliran awal. Sementara gigi dirasa kurang memberi banyak kontribusi dibanding peran dari baffle blocks.

Kata kunci: bendung, pelimpah ogee, roller bucket, gigi(slotted), baffle blocks, kecepatan air, turbulensi, loncatan hidrolis, peredaman energi.
\end{abstract}

\begin{abstract}
Humans have conducted several attempts to convey water from rivers to rice fields, such as by building weirs. As a result of obstructing the river flow, there is a hydraulic jump downstream which causes local scour. This happens when supercritical flow turns into subcritical flow. To reduce energy in the flow, roller bucket and baffle block stilling basin are used. Slotted in the roller bucket stilling basin has a function to break the flow, and the function of the baffle block is to reduce the energy downstream. So that the shape of the slot and block baffles play a role in reducing energy flow. The purpose of this study was to determine the effect of slot shape and baffle block in reducing the energy associated with Reynolds and Froude numbers.

This research was conducted at the Hydraulic Laboratory of the Civil Engineering Study Program at the Faculty of Engineering UMS. This study used an open flume of $0.3 \times 0.6 \times 10 \mathrm{~m}$ with a channel slope of 0.0058 . Using ogee overflow and roller buckets stilling basin with triangular, trapezoidal, semi-circular and concave slot, V, and baffle blocks. The study was conducted with 12 series, each series carried out five (5) running stages with five variations of discharge, so that the total running were 60 runs. Each discharge was tested for hydraulic jump length and energy loss.

The results showed that roller bucket stilling basin with semi-circular slot and concave baffle blocks were most effective in resisting collision forces, reducing flow turbulence, reducing hydraulic jump length, and absorbing energy. That's because flow tangents in rank 2 polynomials have flow directions that cut off the initial flow. Whereas the slots are less contributing than the role of baffle blocks.

Key words: baffle blocks, energy dissipation, flow velocity, hydraulic jump, Ogee type, roller bucket, slotted, turbulence, weir,
\end{abstract}

\section{Pendahuluan}

Bendung merupakan bangunan melintang sungai yang berfungsi menaikan muka air di bagian hulu sampai pada ketinggian tertentu. Akibat dari pembendungan tersebut adalah adanya beda tinggi muka air pada bagian hulu dan hilir sehingga mengakibatkan terjadinya loncatan hidrolik. Hal tersebut berdampak terjadinya gerusan lokal.

Sehingga digunakan kolam olak slotted roller bucket untuk mereduksi gerusan. Terdapat slot/celah (bagian pada antar slot disebut gigi) pada kolam olak jenis ini yang berfungsi memecah aliran dan mengurangi fluktuasi permukaan air pada hilir spillway.

Tetapi, pada kenyataannya masih terjadi gerusan (Setiawan, 2013). Maka, pada ujung kolak dilengkapi dengan baffle blocks untuk menambah reduksi energi. Sehingga tujuan dari penelitian ini untuk mengetahui bentuk gigi slotted dan baffle blocks paling efektif meredam energi pada kolam olak slotted roller bucket.

\section{Tinjauan Pustaka}

Beberapa penelitian yang pernah dilakukan berkaitan dengan peredam energi pada kolam olak diantaranya:

Abdurrosyid, et.all. (2018) melakukan penelitian pengaruh variasi kemiringan tubuh hilir bendung dan penempatan baffle blocks pada kolam olak tipe solid roller bucket terhadap loncatan hidrolis dan peredaman energi. Dari hasil penelitian didapat baffle blocks yang diletakkan pada tengah radius lengkung adalah yang paling efektif dalam meredam turbulensi aliran di hilir pusaran.

Dwi (2015) melakukan peneitian tentang pengaruh penempatan baffle blocks tipe cekung parabolik dan setengah lingkaran pada bendung dengan kolam olak solid roller bucket terhadap panjang loncat air dan kehilangan energi. Didapat hasil susunan baffle blocks paling efektif dalam mereduksi energi kinetik aliran dan panjang loncatan air adalah baffle blocks tipe cekung parabolik dengan posisi awal radius lengkung kolam olak.

Gadang (2018) melakukan penelitian pengaruh penempatan baffle blocks tipe $\mathrm{V}$ terhadap reduksi panjang loncatan dan energi aliran pada pengalir bendung tipe ogee. Hail penelitian didapat bahwa penempatan yang tepat, baffle blocks tipe $\mathrm{V}$ dapat 
mereduksi energi kinetik hingga 74,36\% dan mereduksi panjang loncatan air hingga 29,82\%.

\section{Landasan Teori}

Pelimpah merupakan salah satu komponen dari saluran pengatur aliran, dibuat untuk meninggikan muka air. Akibat dari pembendungan tersebut terjadi perubahan aliran yang cepat dan energi sangat besar yang menimbulkan gerusan di bawah pelimpah (Mays, 1999; Triatmodjo, 1995; Ranga Raju, 1986). Salah satu upaya mengurangi gerusan tersebut adalah dengan menggunakan bangunan peredam energi/kolam olak. Sering kali kolam olak dilengkapi dengan adanya baffle blocks untuk menambah efektifitas redaman energi (Peterka, 1974).

\section{Tipe Aliran pada Bendung}

Saluran terbuka adalah saluran dengan muka air bebas. Tekanan permukaan air pada semua titik di sepanjang saluran adalah sama, biasanya merupakan tekanan atmosfer. Pengaliran melalui pipa (saluran tertutup) yang tidak penuh (terdapat muka air bebas) merupakan aliran terbuka (Triadmojo, 2003).

\section{Bilangan Reynolds}

Reynolds dalam percobaannya menyimpulkan bahwa perubahan aliran laminar ke aliran turbulen terjadi untuk suatu harga disebut dengan bilangan Reynolds (Re). Angka ini menyatakan rasio perbandingan antara gaya kelembaman dan gaya kekentalan.

$$
\begin{aligned}
& \mathbf{R e}=\frac{\mathbf{v} \cdot \mathbf{R}}{\mathbf{v}} \\
& \text { dengan: Re = Angka Reynolds, } \\
& \mathrm{v} \quad=\text { Kecepatan aliran }(\mathrm{m} / \mathrm{det}) \text {, } \\
& \mathrm{R}=\text { Jari-jari hidrolis (m), } \\
& v \quad=\text { Kekentalan kinematik }\left(\mathrm{m}^{2} / \mathrm{det}\right)
\end{aligned}
$$

\section{Angka Froude}

Akibat gaya gravitasi terhadap karakteristik aliran berdasarkan bilangan Froude ( $\mathrm{Fr})$ dibagi menjadi tiga yaitu, aliran kritis $(\mathrm{Fr}=$ $1)$, aliran subkritis $(\mathrm{Fr}<1)$, aliran superkritis $(\mathrm{Fr}>1)$. Angka Froude (Fr) merupakan rasio perbandingan antara gaya inersia dengan gaya gravitasi.

$$
\mathrm{Fr}=\frac{\mathrm{v}}{\sqrt{\mathrm{g.d}_{1}}}
$$
dengan: $\mathrm{Fr}$

$$
\mathrm{v}
$$$$
=\text { Angka Froude, }
$$

= Kecepatan aliran $(\mathrm{m} / \mathrm{det})$,

$=$ Percepatan gaya gravitasi $\left(\mathrm{m} / \mathrm{det}^{2}\right)$, $\mathrm{d}_{1}$ = Kedalaman aliran $(\mathrm{m})$.

\section{Loncatan Air}

Loncatan air merupakan gerakan air yang terjadi akibat aliran superkritis menjadi subkritis. Ven Te Chow, secara teoritis menggolongkan loncatan air menjadi beberapa tipe yang dipengaruhi oleh besarnya angka Froude (Fr), yaitu:

1. Loncatan berombak (undular jump) apabila angka Froude $\mathrm{Fr}=1-1,7$,

2. Loncatan lemah (waek jump) apabila angka Froude $\mathrm{Fr}=1,7$ $-2,5$,

3. Loncatan berosilasi (oscillation jump) apabila angka Froude $\mathrm{Fr}=2,5-4,5$,

4. Loncatan tetap (steady jump) apabila angka Froude $\mathrm{Fr}=4,5$ $-9,0$,

5. Loncatan kuat (string jump) apabila angka Froude $\mathrm{Fr} \geq 9,0$,

\section{Energi Spesifik}

Energi spesifik pada suatu penampang saluran dinyatakan sebagai energi tiap satuan berat pada setiap penampang saluran diukur terhadap dasar saluran (Anggraini, 1997).

$$
\begin{aligned}
& E_{s}=d \cdot \cos \theta+\alpha \cdot \frac{v^{2}}{2 g} \\
& \text { dengan: } \mathrm{E}_{\mathrm{s}} \quad=\text { Energi Spesifik }(\mathrm{m}) \text {, } \\
& \mathrm{d} \quad=\text { Kedalaman }(\mathrm{m}) \text {, } \\
& \theta \quad=\text { Sudut kemiringan dasar saluran }\left({ }^{\circ}\right) \text {, } \\
& \mathrm{v} \quad=\text { Kecepatan aliran }(\mathrm{m} / \mathrm{det}) \text {, } \\
& \text { g } \quad=\text { Percepatan gaya gravitasi }\left(\mathrm{m} / \mathrm{det}^{2}\right) \text {. }
\end{aligned}
$$

\section{Gaya Hambatan (Drag Force)}

Gaya aliran yang menumbuk baffle blocks menimbulkan gaya reaksi yang sama $\left(\mathrm{F}_{1}=\mathrm{F}_{2}\right)$. Gaya yang bekerja pada baffle blocks terhadap aliran pada kolam olak roller bucket dimisalkan seperti gaya hambat yang berkerja pada sedimen terhadap aliran.

$$
\begin{aligned}
\mathbf{F}_{\mathbf{D}}=\mathbf{C}_{\mathbf{D} \cdot} \frac{\mathbf{1}}{\mathbf{2}} \boldsymbol{\rho}_{\mathbf{w}} \cdot \mathbf{v}^{\mathbf{2}} \cdot \mathbf{A} & =\boldsymbol{\tau} . \mathbf{A} \\
\text { dengan }: \mathrm{F}_{\mathrm{D}} & =\text { Gaya hambatan }(\mathrm{N}), \\
\mathrm{C}_{\mathrm{D}} & =\text { Coeffisient drag } / \text { Koefisien hambatan, } \\
\rho_{\mathrm{w}} & =\text { Rapat massa air }\left(\mathrm{kg} / \mathrm{m}^{3}\right), \\
\mathrm{V} & =\text { Kecepatan aliran }(\mathrm{m} / \mathrm{dt}), \\
\mathrm{A} & =\text { Luas penampang basah }\left(\mathrm{m}^{2}\right), \\
\tau & =\text { Tegangan geser }\left(\mathrm{N} / \mathrm{m}^{2}\right) .
\end{aligned}
$$

$C_{D}$ dapat diketahui melalui gambar grafik hubungan $C_{D}, R e$, dan Sf oleh Schulz, Wilde, dan Albertson.

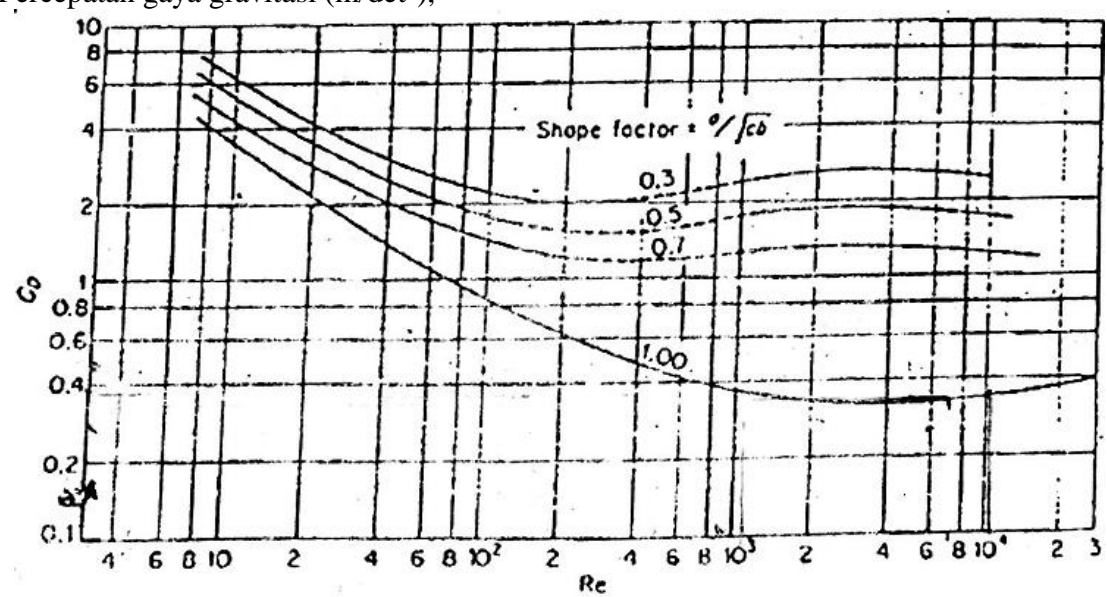

\section{Mercu Pelimpah}

Bendung merupakan salah satu bangunan air yang dibangun melintang sungai guna meninggikan tinggi muka air sungai hingga ketinggian tertentu sehingga dapat dialirkan ke tempat
Reynolds (Re) untuk Shape Factor (Sf) (Abdurrosyid, 2003) yang membutuhkan. Sedangkan mercu merupakan bagian paling atas dari pelimpah, yang berhubungan langsung dengan air yang melimpah. Sehingga bentuk mercu berpengaruh terhadap karakteristik aliran pada hilir. Pada umumnya di Indonesia terdapat dua tipe mercu pelimpah untuk bendung yaitu, tipe bulat dan tipe Ogee. 




mercu tipe ogee

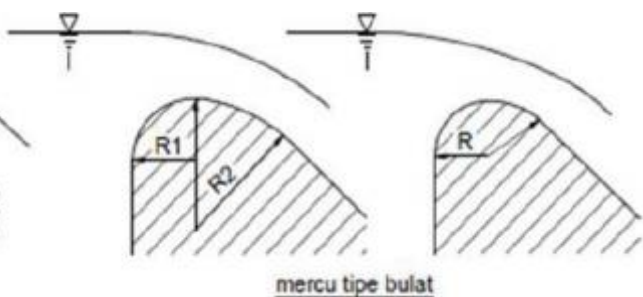

mercu tipe bulat

\section{Peredam Energi Tipe Slotted Roller Bucket}

Disipasi energi kinetik pada kolam olak tipe slotted roller bucket disebabkan oleh dua pusaran air yang terbentuk oleh prilaku hidrolis dari kolam olak ini, yaitu surface roller atau pusaran pada atas bucket yang bergerak berlawanan arah jarum jam (jika aliranya dari kiri ke kanan) dan ground roller atau pusaran pada hilir kolam olak bergerak searah jarum jam.

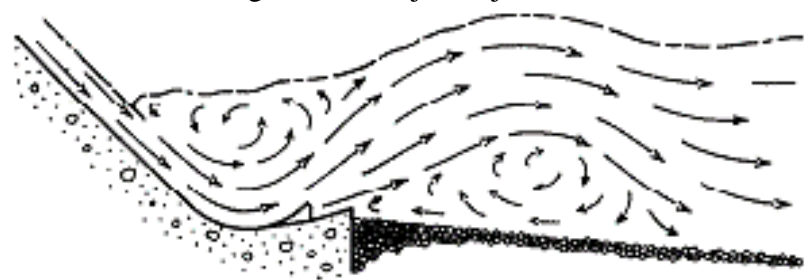

Gambar 3.Pemecahan Energi Kolam Olak Slotted Roller Bucket (Peterka, 1964)

\section{Metodologi Penelitian}

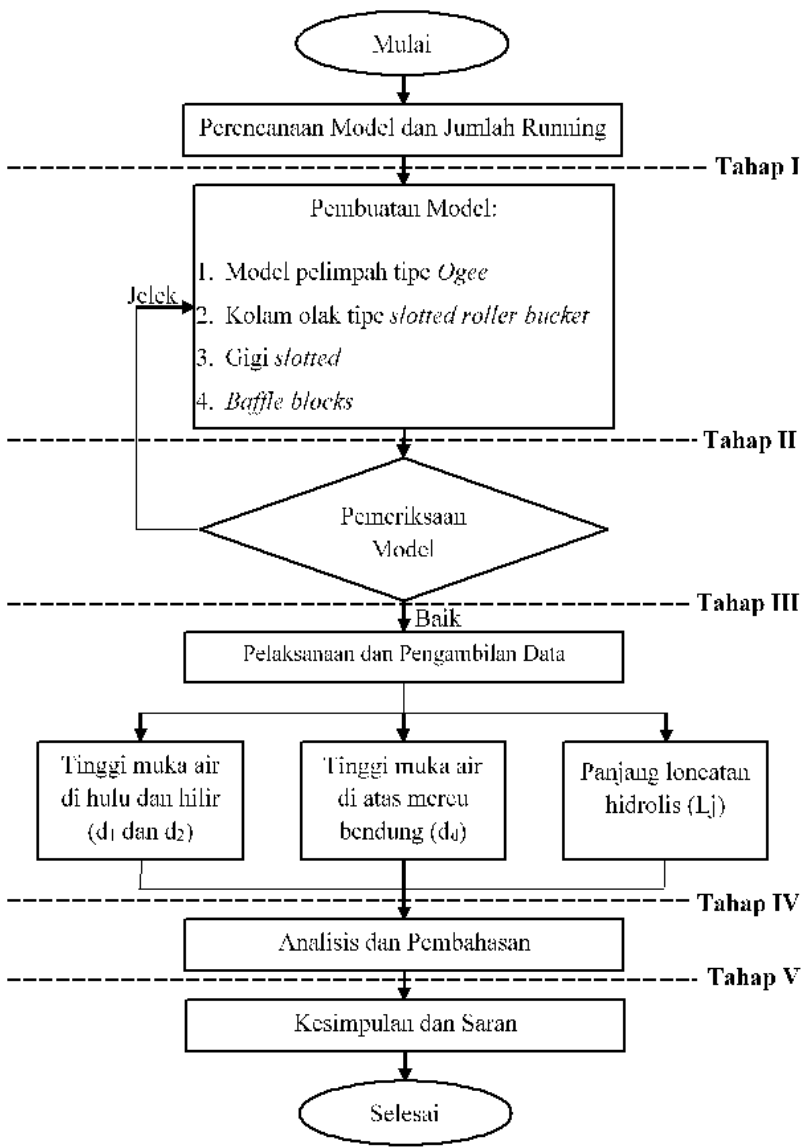

Gambar 4. Bagan Alur Penelitian

\section{Perencanaan Model Pelimpah}

Bangunan pelimpah didesain dengan debit (Q) maksimum agar dapat digunakan debit variasi yang beragam.
a. Debit maksimum (Q)
$=0,005 \mathrm{~m}^{3} / \mathrm{det}$
b. Lebar saluran
$=0,30 \mathrm{~m}$
c. Tinggi pelimpah
$=0,24 \mathrm{~m}$
d. Dicoba d
e. $\operatorname{Kecepatan}(\mathrm{v})$

$$
=0,0384 \mathrm{~m}
$$

$$
\begin{aligned}
& \mathrm{v}=\frac{\mathrm{Q}}{\left(\mathrm{H}+\mathrm{d}_{\mathrm{d}}\right) \cdot \mathrm{B}} \\
& \mathrm{v}=\frac{0,005}{(0,24+0,0384) \cdot 0,30} \\
& \quad \mathrm{v}=0,0599 \mathrm{~m}
\end{aligned}
$$

f. Ketinggian tek. total $\left(\mathrm{h}_{\mathrm{c}}\right)$

$$
\begin{aligned}
& \mathrm{h}_{\mathrm{c}}=\mathrm{d}_{\mathrm{d}}+\frac{\mathrm{v}^{2}}{2 \mathrm{~g}} \\
& \mathrm{~h}_{\mathrm{c}}=0,0384+\frac{0,0599^{2}}{2 \times 9,81} \\
& \mathrm{~h}_{\mathrm{c}}=0,0386 \mathrm{~m}
\end{aligned}
$$

g. Menghitung koefisien $\mathrm{C}_{d}$

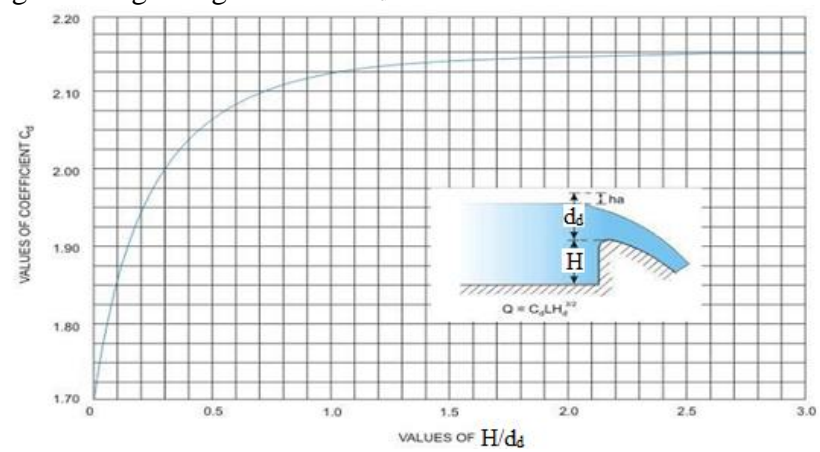

Gambar 5. Hubungan Koefisien Peluapan Mercu Ogee Hubungan antara $\mathrm{H} / \mathrm{d}_{\mathrm{d}}$ (Hydraulic Structures for Flow Diversion and Storage, Version 2 CE IIT - Kharangpur)

Dari gambar di atas dengan nilai $\mathrm{H} / \mathrm{d}_{\mathrm{d}}=6,25$ dan ektrapolasi dari persamaan $y=0,016 x+2,102$ didapat nilai $C_{D}=2,202$, maka didapat kontrol debit (Q) berikut sebagai berikut:

$$
\begin{aligned}
& \mathrm{Q}=\mathrm{C}_{\mathrm{D}} \cdot \mathrm{B} \cdot \mathrm{h}_{\mathrm{c}}^{\frac{3}{2}} \\
& \mathrm{Q}=2,202 \times 0,3 \times 0,0386^{\frac{3}{2}} \\
& \mathrm{Q}=0,005 \mathrm{~m}^{3} / \mathrm{dt}
\end{aligned}
$$

\section{Perencanaan Kolam Olak}

a. $\quad$ Debit maksimum $(\mathrm{Q})$

$=0,005 \mathrm{~m}^{3} / \mathrm{det}$

b. Lebar efektif bendung (B)

c. Tinggi air di hilir bendung $\left(\mathrm{d}_{\mathrm{d}}\right)$

d. Tebal kolam olak $\left(\mathrm{s}_{1}\right)$

$=0,30 \mathrm{~m}$

$=0,0384 \mathrm{~m}$

$=0,017 \mathrm{~m}$

e. $\operatorname{Kecepatan}(\mathrm{v})$

$$
\begin{aligned}
& \mathrm{v}=\sqrt{2 \mathrm{~g} \times\left(\frac{1}{2} \mathrm{~d}_{\mathrm{d}} \times\left(\mathrm{H}-\mathrm{s}_{1}\right)\right)} \\
& \mathrm{v}=\sqrt{2 \times 9,81 \times\left(\frac{1}{2} \cdot 0,0384+(0,24-0,017)\right)} \\
& \mathrm{v}=2,1798 \mathrm{~m} / \mathrm{dt}
\end{aligned}
$$

f. Tinggi air pada mercu (d) = 
$\mathrm{d}=\frac{\mathrm{Q}}{(\mathrm{B} \times \mathrm{v})}=\frac{0,005}{(0,30 \times 2,1798)}=0,01 \mathrm{~m}$

g. Bilangan Froude (Fr)

$\mathrm{Fr}=\frac{\mathrm{v}}{\sqrt{\mathrm{g} \times \mathrm{d}_{1}}}=\frac{2,1798}{\sqrt{9,81 \times 0,01}}=7,960$

h. Radius cekung bucket $\left(\mathrm{R}_{\min }\right)$ dari gambar 6 dengan bilangan Froude $=7,960$ didapat:

$\frac{R_{\min }}{\left(d+\frac{v_{1}^{2}}{2 g}\right)}=0,195$

$\mathrm{R}_{\min }=0,195 \times\left(0,01+\frac{2,1798^{2}}{2 \times 9,81}\right)=0,05 \mathrm{~m}$

i. Tinggi minimum tailwater $\left(\mathrm{T}_{\mathrm{min}}\right)$ dari gambar 7 dengan bilangan Froude $\quad=\quad 7,960$ dan $\frac{\mathrm{R}_{\min }}{\left(\mathrm{d}+\frac{v_{1}^{2}}{2 \mathrm{~g}}\right)}=0,195$ didapat:

$\frac{\mathrm{T}_{\min }}{\mathrm{d}}=12,36$

$\mathrm{T}_{\min }=0,01 \times 12,36=1,236 \mathrm{~m}$

j. Tinggi maksimum tailwater $\left(\mathrm{T}_{\max }\right)$ dari gambar 8 dengan bilangan Froude $=7,960$ dan $\frac{R_{\min }}{\left(d+\frac{v_{1}^{2}}{2 g}\right)}=0,195$ didapat:

$\frac{\mathrm{T}_{\max }}{\mathrm{d}}=18,00$

$\mathrm{T}_{\max }=0,01 \times 18,00=1,80 \mathrm{~m}$

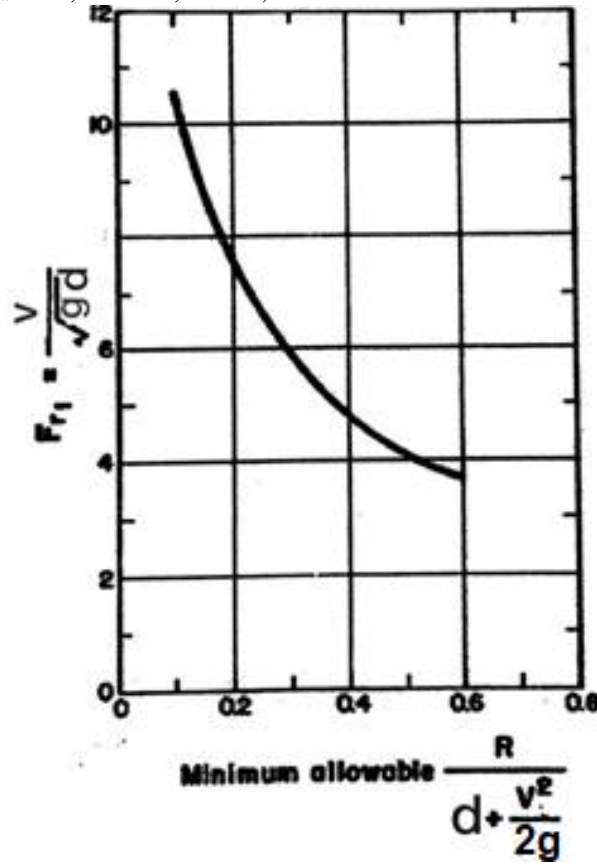

Gambar 6. Hubungan antara Fr dengan Parameter Radius Bucket

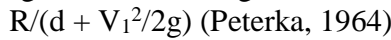



Gambar 7. Hubungan antara Fr dan $\mathrm{R} /\left(\mathrm{d}+\mathrm{V}_{1}^{2} / 2 \mathrm{~g}\right)$ dengan $\mathrm{T}_{\mathrm{min}} / \mathrm{d}_{1}$ (Peterka, 1964)

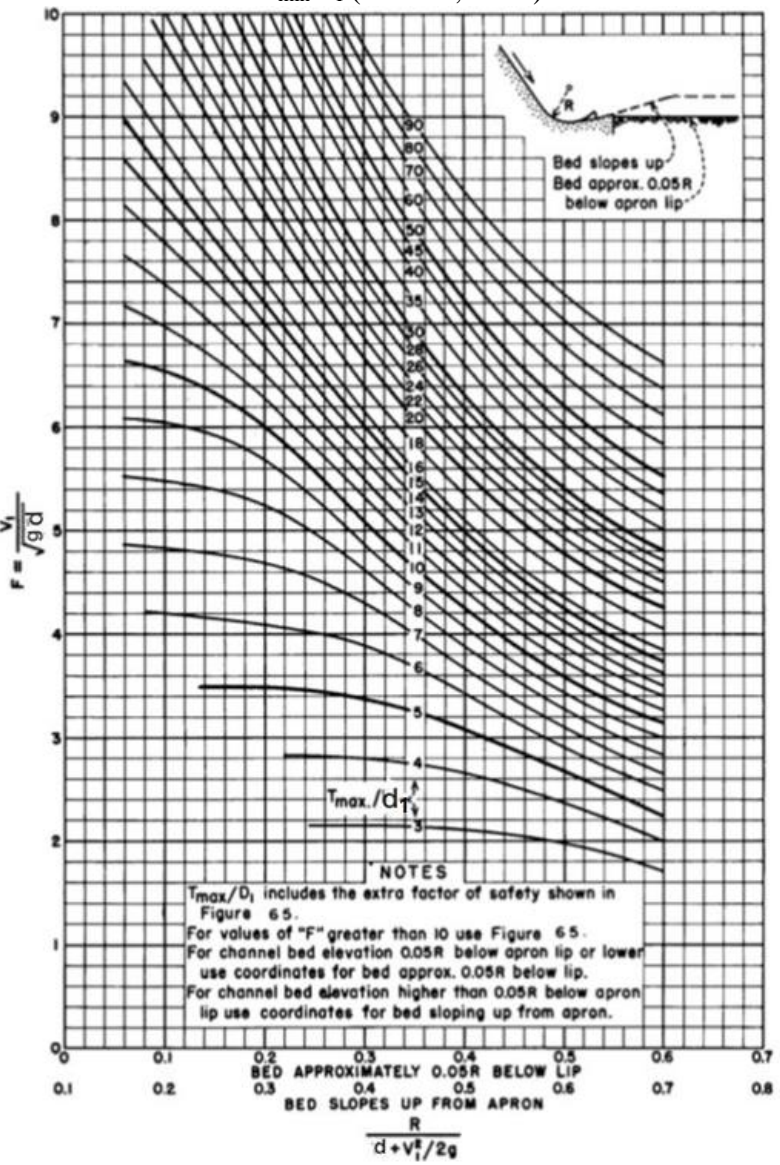

Gambar 8. Hubungan antara Frdan $\mathrm{R} /\left(\mathrm{d}+\mathrm{V}_{1^{2}} / 2 \mathrm{~g}\right)$ dengan $\mathrm{T}_{\max } / \mathrm{d}_{1}$ (Peterka, 1964) 


\section{Perencanaan Baffle Blocks}

Baffle blocks terbuat dari balok kayu dengan variasi bentuk cekung, $\mathrm{V}$ dan kubus dengan dimensi $\frac{5}{12} \mathrm{R}(0,02 \times 0,02 \times 0,02 \mathrm{~m})$.
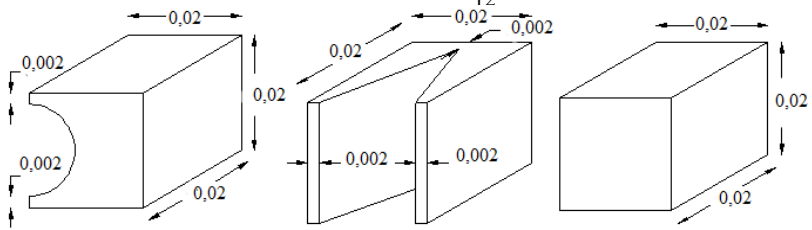

Gambar 9. Baffle Block Tipe Cekung, V, dan Kubus

\section{Perencanaan Gigi}

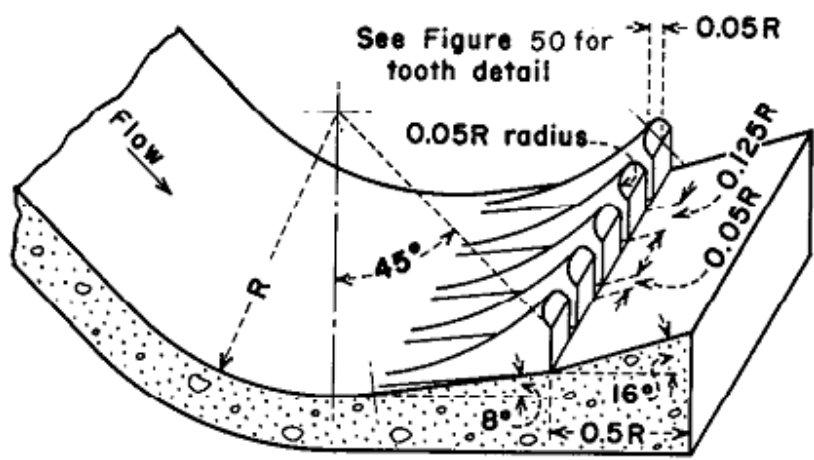

Gambar 10. Kolam Olak Tipe Slotted Roller Bucket (Peterka, 1964)

Lebar gigi $\quad=0,125 \times \mathrm{R}=0,125 \times 0,05=0,006 \mathrm{~m}$ Lebar slot $\quad=0,05 \times \mathrm{R}=0,05 \times 0,05=0,003 \mathrm{~m}$
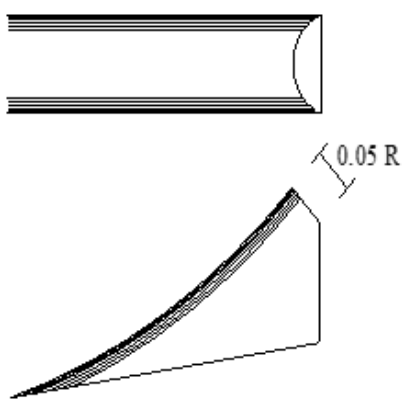

$0.125 \mathrm{R} \quad 0.125 \mathrm{R} \quad 0.125 \mathrm{R}$
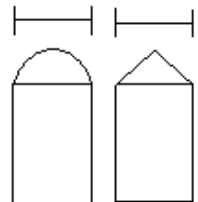

Gambar 11. Gigi Tipe Setengah Lingkaran, Segitiga, dan Trapesium

Tabel 1. Running Penelitian

\begin{tabular}{cccc}
\hline No & Seri & $\begin{array}{c}\text { Bentuk Baffle } \\
\text { Blocks }\end{array}$ & Bentuk Gigi \\
\hline 1 & S01.X & - & Segitiga \\
2 & S02.X & - & Segitiga \\
3 & S03.X & - & Segitiga \\
4 & S04.X & - & Segitiga \\
5 & S05.X & - & Segitiga \\
6 & T01.X & - & Trapesium \\
7 & T02.X & - & Trapesium \\
8 & T03.X & - & Trapesium \\
9 & T04.X & - & Trapesium \\
10 & T05.X & - & Trapesium \\
11 & L01.X & - & Setengah Lingkaran \\
12 & L02.X & - & Setengah Lingkaran \\
13 & L03.X & - & Setengah Lingkaran \\
14 & L04.X & - & Setengah Lingkaran
\end{tabular}

15 L05.X

16

S01.K

Kubus

Setengah Lingkaran

17

S02.K

Kubus

Segitiga

Segitiga

Segitiga

Segitiga

Segitiga

Segitiga

Segitiga

Segitiga

Segitiga

Segitiga

Segitiga

Segitiga

Segitiga

Segitiga

Segitiga

Trapesium

Trapesium

Trapesium

Trapesium

Trapesium

Trapesium

36 T01.V

V

Trapesium

\begin{tabular}{cccc}
37 & T02.V & V & Trapesium \\
\hline No & Seri & $\begin{array}{c}\text { Bentuk Baffle } \\
\text { Blocks }\end{array}$ & Bentuk Gigi \\
\hline 38 & T03.V & V & Trapesium \\
39 & T04.V & V & Trapesium \\
40 & T05.V & V & Trapesium \\
41 & T01.C & Cekung & Trapesium \\
42 & T02.C & Cekung & Trapesium \\
43 & T03.C & Cekung & Trapesium \\
44 & T04.C & Cekung & Trapesium \\
45 & T05.C & Cekung & Trapesium
\end{tabular}

$46 \quad$ L01.K

Kubus

Setengah Lingkaran

47 L02.K

Kubus

Setengah Lingkaran

$48 \quad$ L03.K

Kubus

Setengah Lingkaran

49 L04.K

Kubus

Setengah Lingkaran

$50 \quad$ L05.K

Kubus

Setengah Lingkaran

51 L01.V

V

Setengah Lingkaran

52 L02.V

V

Setengah Lingkaran

53 L03.V

V

Setengah Lingkaran

54 L04.V

V

Setengah Lingkaran

55 L05.V

V

56 L01.C

Cekung

Setengah Lingkaran

57 L02.C

Cekung

Setengah Lingkaran

58 L03.C Cekung

Setengah Lingkaran

59 L04.C Cekung

Setengah Lingkaran

60 L05.C Cekung

Setengah Lingkaran 
Keterangan tabel:

a. Huruf (X, C, K dan V) : Tanpa baffle blocks (X), baffle blocks tipe cekung (C), baffle blocks tipe kubus (K), dan baffle blocks tipe $\mathrm{V}(\mathrm{V})$

b. Angka (1, 2, 3, 4, dan 5): debit dengan lima variasi
$\mathrm{Q}_{1}=0,00015 \mathrm{~m}^{3} / \mathrm{det}$
$\mathrm{Q}_{4}=0,00040 \mathrm{~m}^{3} / \mathrm{det}$
$\mathrm{Q}_{2}=0,00020 \mathrm{~m}^{3} / \mathrm{det}$
$\mathrm{Q}_{5}=0,00050 \mathrm{~m}^{3} / \mathrm{det}$

$\mathrm{Q}_{3}=0,00030 \mathrm{~m}^{3} / \mathrm{det}$

c. Huruf (S, T, dan L): Bentuk gigi segitiga (S), gigi trapesium (T), dan gigi setengah lingkaran (L)

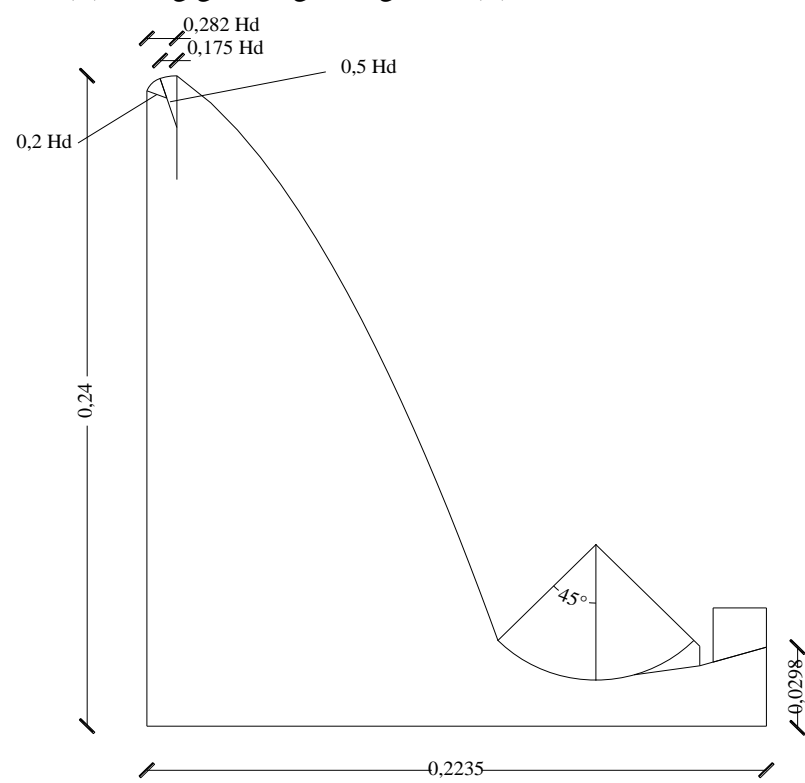

Gambar 12. Tampang Lintang Bendung Tipe Ogee dan Kolam Olak Tipe Slotted Roller Bucket
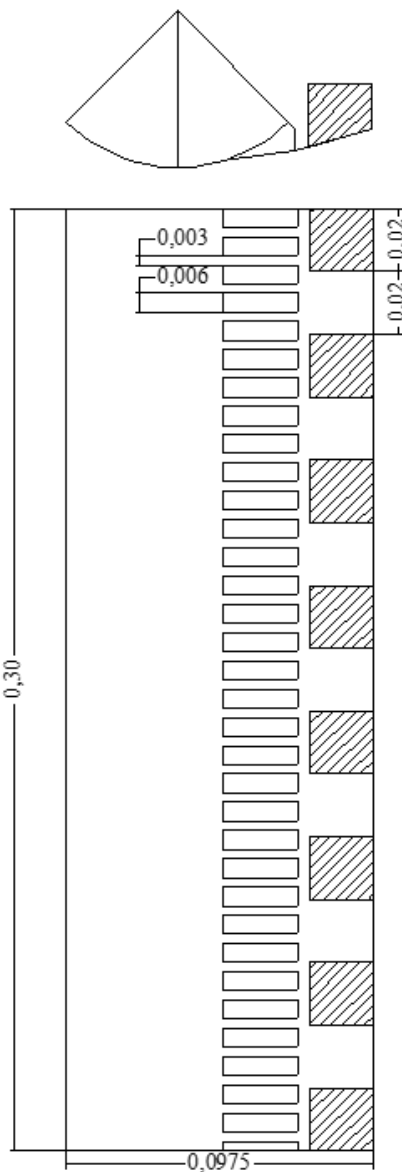

Gambar 13. Perletakan Gigi dan Baffle Blocks

\section{Hasil dan Pembahasan}

Penelitian dilakukan dengan mengalirkan air pada flume melewati pelimpah ogee dengan 5 variasi debit $\left(0,0015 \mathrm{~m}^{3} / \mathrm{det}\right.$, $0,0020 \mathrm{~m}^{3} / \mathrm{det}, 0,0030 \mathrm{~m}^{3} / \mathrm{det}, 0,0040 \mathrm{~m}^{3} / \mathrm{det}$, dan $0,0050 \mathrm{~m}^{3} / \mathrm{det}$ ) menggunakan pompa air, dilakukan pada 60 kali running penelitian. Hasil analisis meliputi:

\section{Gaya yang Ditahan Baffle Blocks}

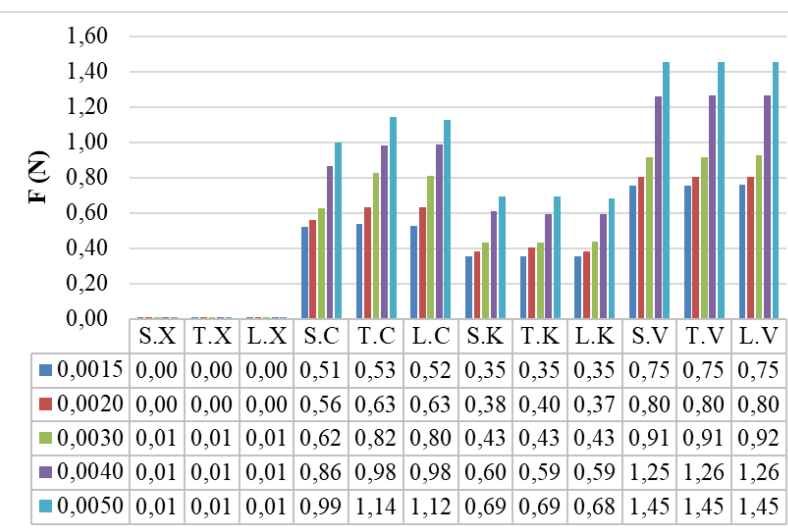

Gambar 14. Hubungan Variasi Debit $\left(\mathrm{m}^{3} / \mathrm{dt}\right)$ dengan $\mathrm{F}(\mathrm{N})$ Gambar 14 menunjukan bahwa tidak terjadi perbedaan reduksi gaya yang signifikan terhadap perubahan bentuk gigi segitiga, setengah lingkaran atau trapezium. Perbedaan signifikan terjadi antara gaya yang tereduksi pada kolam olak slotted roller bucket tanpa baffle blocks dan dengan baffle blocks. Namun, dapat diketahui seri baffle blocks gigi tipe V mereduksi energi paling efektif.

Hipotesa awal ditinjau secara teknis, bahwa baffle blocks tipe $\mathrm{V}$ memiliki luas penampang lebih besar dibandingkan tipe cekung atau kubus. Hal ini disebabkan karena besarnya luas penampang yang menahan aliran berbanding lurus dengan nilai gaya aliran yang ditahan. Sehingga gaya yang ditahan baffle blocks tipe $\mathrm{V}$ lebih besar dibanding baffle blocks tipe yang lain. 


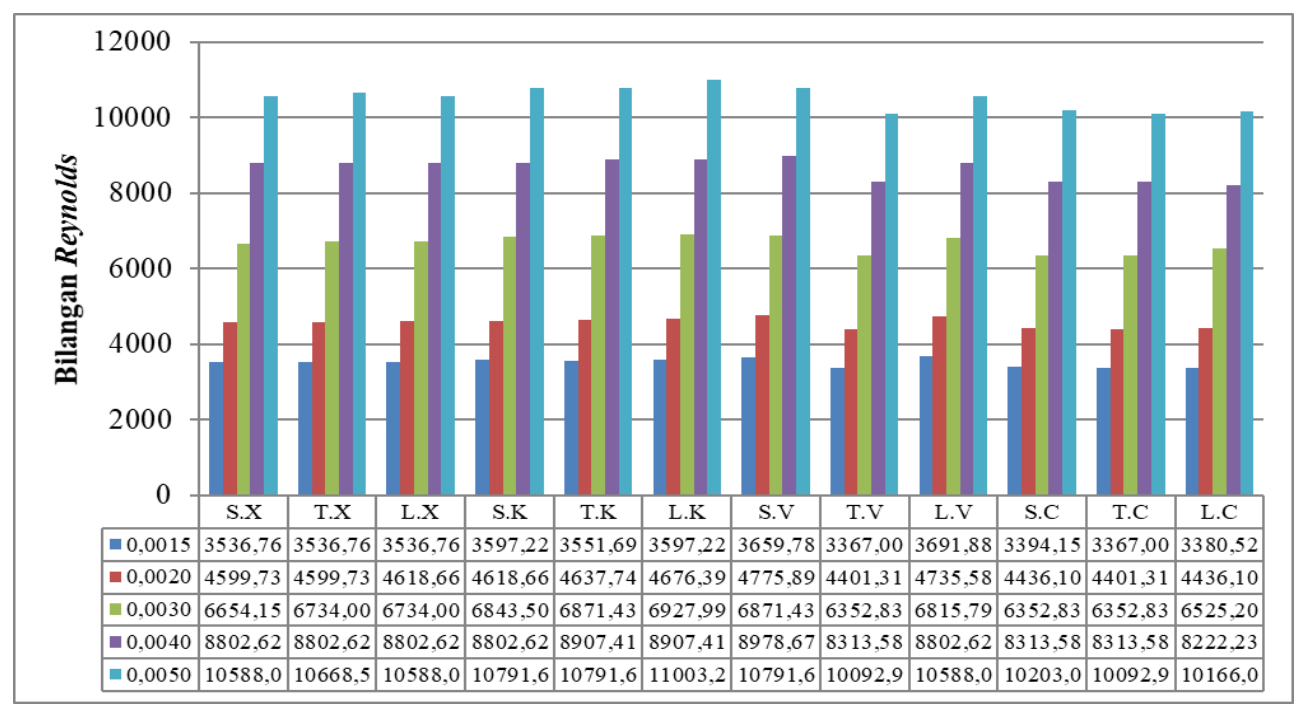

Gambar 15. Hubungan Variasi Debit $\left(\mathrm{m}^{3} / \mathrm{dt}\right)$ dengan Bilangan Reynolds

Gambar 15. menunjukkan bahwa semua aliran yang terjadi pada yang merupakan seri kolam olak gigi trapezium baffle blocks tipe semua perlakuan adalah turbulen, karena memiliki nilai $\mathrm{Re}>\quad \mathrm{V}$ dan gigi setengah lingkaran baffle blocks tipe cekung.

1000. Semakin bertambahnya debit aliran, bilangan Reynolds di hilir pusaran semakin besar. Hal ini dikarenakan kekentalan kinematik dianggap sama. Dari penelitian tersebut hasil paling efektif meredam energi turbulensi di hilir adalah seri T.V dan L.C

\section{Angka Froude dengan Variasi Debit}

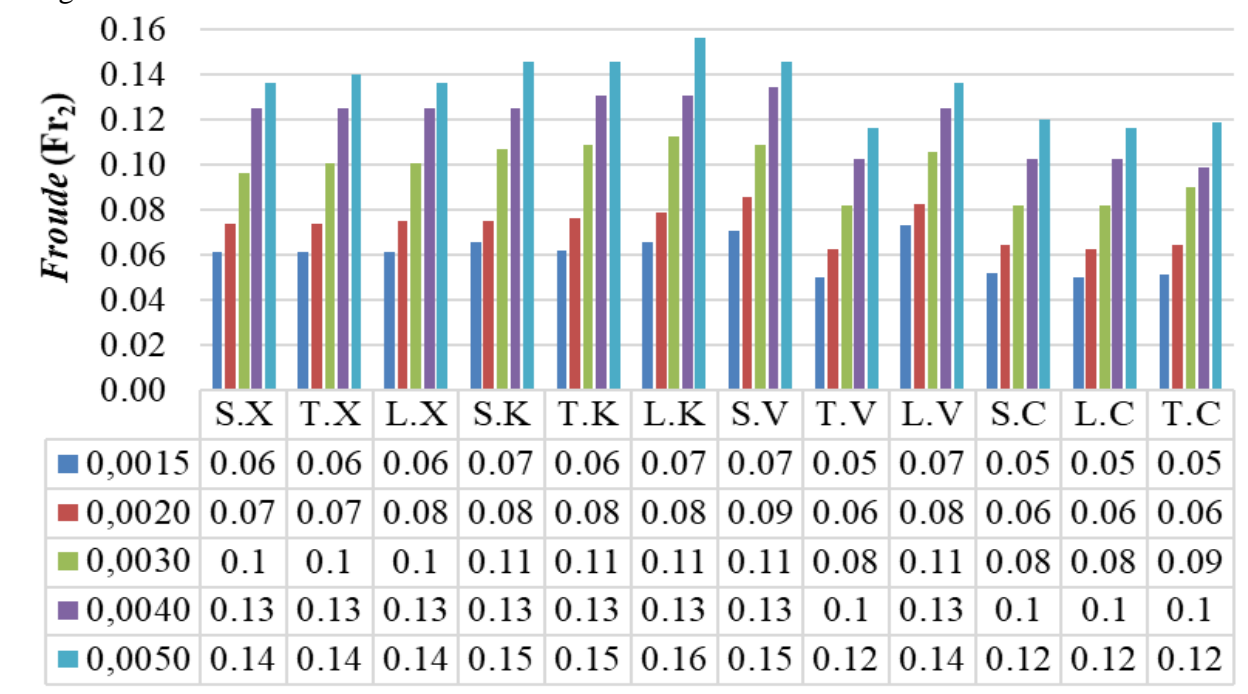

Gambar 16. Hubungan Variasi Debit ( $\left.\mathrm{m}^{3} / \mathrm{det}\right)$ dengan Bilangan Froude

Gambar 16 menunjukan bahwa semua aliran yang terjadi pada hilir kolam olak adalah aliran subkritis, karena besarnya $\mathrm{Fr}<1$. Semakin bertambahnya debit aliran, bilangan Froude di hilir pusaran semakin besar. Dari penelitian tersebut hasil paling efektif meredam energi turbulensi di hilir pusaran adalah seri T.V dan L.C yang merupakan seri kolam olak gigi trapeziun baffle blocks tipe $\mathrm{V}$ dan gigi setengah lingkaran baffle blocks tipe cekung.

\section{Kehilangan Energi}

Kolam olak dibuat untuk meredam energi, semakin besar kehilangan energi pada aliran tersebut, maka semakin baik peredaman energinya. Kehilangan energi pada aliran melalui tubuh bendung sampai dengan melewati pusaran air adalah hasil dari perhitungan energi di hulu bendung dikurangi dengan energi pada akhir olakan.

a. Dalam kaitan dengan angka Reynolds

Tabel 2. Koreksi Unjuk Kerja Kehilangan Energi Terhadap Energi Awal (hf/E $\left.\mathrm{E}_{1}\right)$ dengan Angka Reynolds Awal $\left(\mathrm{Re}_{1}\right)$

\begin{tabular}{ccccc}
\hline No & Seri & $\begin{array}{c}\text { Re terhadap Re } \\
\text { tanpa baffle blocks } \\
(\%)\end{array}$ & $\begin{array}{c}\text { hf } \\
\text { terhadap } \\
\text { E }_{1}(\%)\end{array}$ & Chek \\
\hline 1 & S.X & $2,65 \%$ & $63,63 \%$ & $1,69 \%$ \\
2 & T.X & $2,19 \%$ & $63,97 \%$ & $1,40 \%$ \\
3 & L.X & $2,37 \%$ & $63,91 \%$ & $1,51 \%$ \\
4 & S.C & $6,87 \%$ & $59,67 \%$ & $4,10 \%$ \\
5 & T.C & $6,78 \%$ & $59,85 \%$ & $4,06 \%$ \\
6 & L.C & $7,36 \%$ & $59,26 \%$ & $4,36 \%$ \\
7 & S.K & $1,31 \%$ & $64,86 \%$ & $0,85 \%$ \\
8 & T.K & $1,00 \%$ & $64,99 \%$ & $0,65 \%$ \\
9 & L.K & $0,00 \%$ & $65,82 \%$ & $0,00 \%$ \\
10 & S.V & $0,10 \%$ & $66,13 \%$ & $0,07 \%$ \\
11 & T.V & $7,36 \%$ & $59,26 \%$ & $4,36 \%$ \\
12 & L.V & $1,36 \%$ & $65,41 \%$ & $0,89 \%$ \\
\hline
\end{tabular}




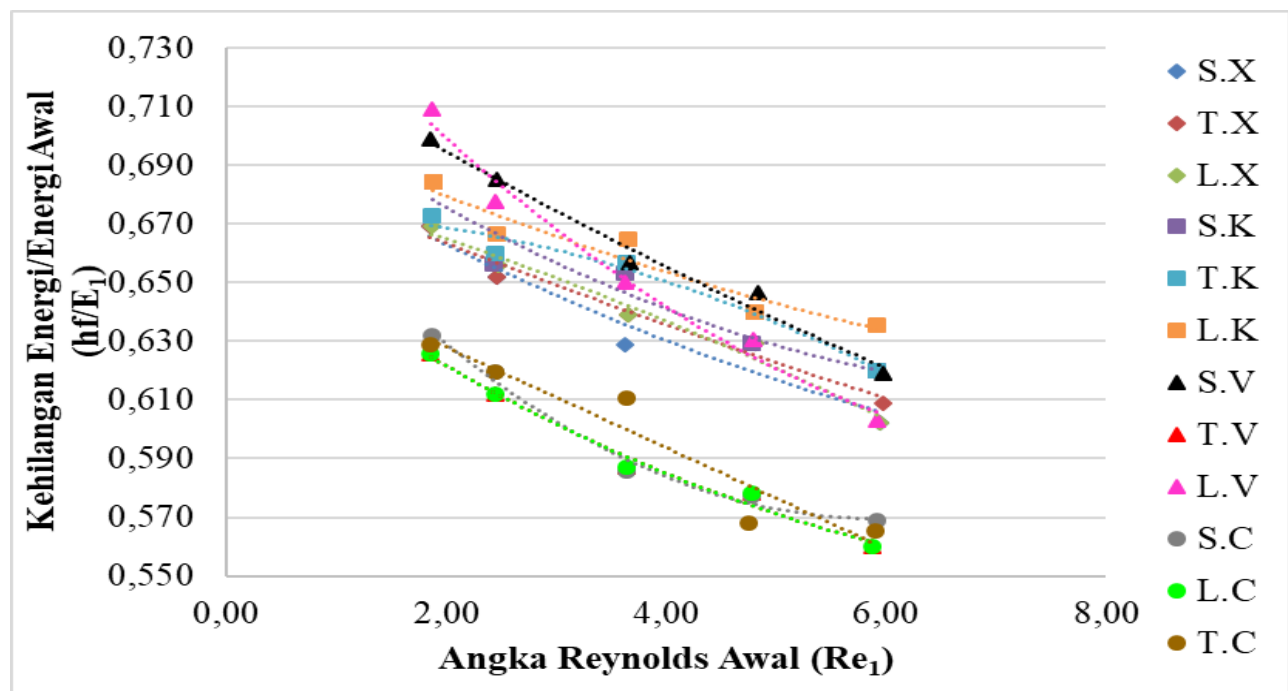

Gambar 17. Hubungan Perbandingan Kehilangan Energi Terhadap Energi Awal (hf/E 1 ) dengan Angka Reynolds Awal ( $\left.\operatorname{Re}_{1}\right)$ Regresi Polynomial

Tabel 2 di atas, menunjukan bahwa bentuk gigi dan baffle blocks paling efektif untuk meredam energi aliran dan meredam turbulensi adalah seri L.C (yaitu gigi setengah lingkaran, baffle blocks tipe cekung) dengan persamaan polynomial didapat koefisien korelasi sebesar 0,9899 dan unjuk kerja sebesar 4,36\%. Hubungan kehilangan energi $\left(\mathrm{m}^{3} / \mathrm{det}\right)$ dengan angka Reynolds menghasilkan persamaan yang paling efektif:

$\mathrm{hf} / \mathrm{E}_{1}=0,0015 \operatorname{Re}_{1}^{2}-0,0274 \operatorname{Re}_{1}+0,6703$.

b. Dalam kaitan dengan bilangan Froude

Tabel 3. Koreksi Unjuk Kerja Kehilangan Energi Terhadap Energi Awal (hf/E 1 ) dengan Bilangan Froude $\left(\mathrm{Fr}_{2}\right)$

\begin{tabular}{|c|c|c|c|c|c|c|c|c|c|}
\hline \multirow{3}{*}{ No } & \multirow{3}{*}{ Seri } & \multirow{3}{*}{$\begin{array}{c}\text { Fr terhadap Fr } \\
\text { tanpa baffle } \\
\text { blocks }(\%)\end{array}$} & \multirow{3}{*}{$\begin{array}{l}\text { hf } \\
\text { terhadap } \mathrm{E}_{1} \\
(\%)\end{array}$} & \multirow{3}{*}{ Chek } & 9 & L.V & $4,12 \%$ & $65,41 \%$ & $2,69 \%$ \\
\hline & & & & & 10 & S.C & $22,87 \%$ & $59,67 \%$ & $13,64 \%$ \\
\hline & & & & & 11 & L.C & $24,26 \%$ & $59,85 \%$ & $14,52 \%$ \\
\hline 1 & S.X & $9,67 \%$ & $63,63 \%$ & $6,15 \%$ & 12 & T.C & $22,47 \%$ & $59,26 \%$ & $13,32 \%$ \\
\hline
\end{tabular}

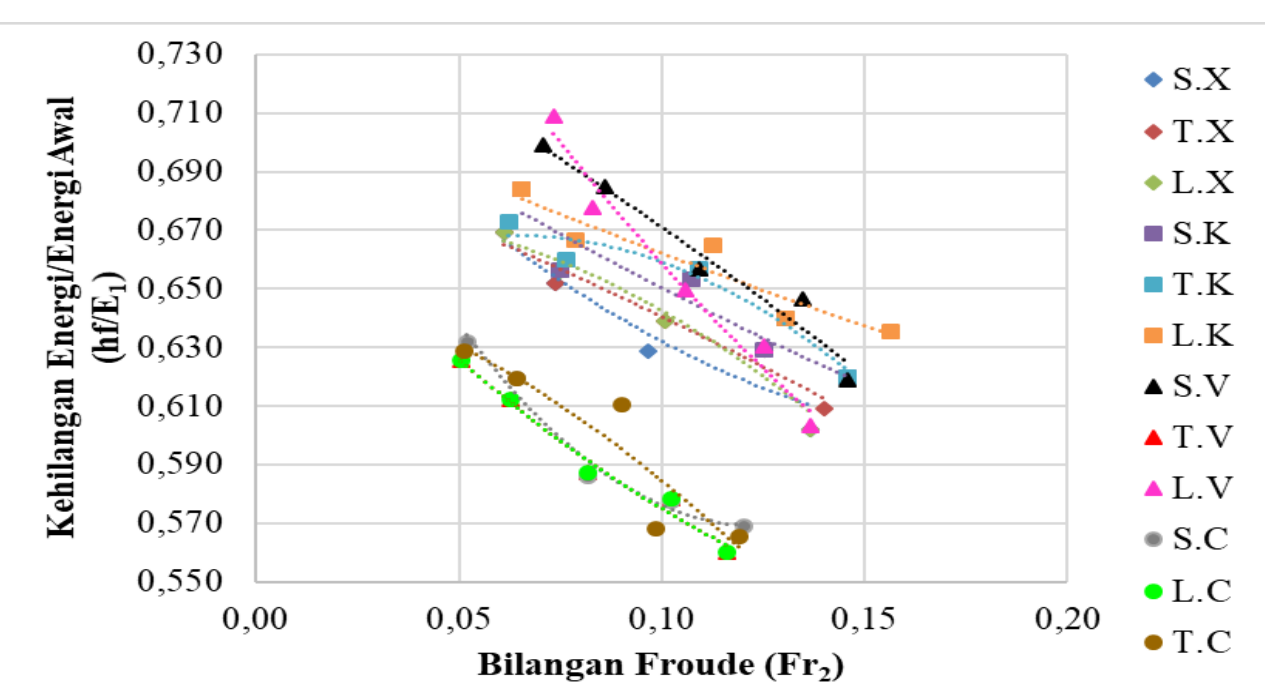

Gambar 18. Hubungan Perbandingan Kehilangan Energi Terhadap Energi Awal (hf/E1) dengan Bilangan Froude ( $\left.\mathrm{Fr}_{2}\right) \mathrm{Regresi}$ Polynomial

Tabel 3 di atas, menunjukan bahwa bentuk gigi dan baffle blocks yang paling efektif untuk meredam loncatan air adalah seri L.V (yaitu gigi setengah lingkaran, baffle blocks tipe V) dengan persamaan polynomial didapat koefisien korelasi yaitu 0,9907 dan unjuk kerja sebesar $14,52 \%$. Hubungan panjang loncatan air (m) dengan kehilangan energi $\left(\mathrm{m}^{3} / \mathrm{dt}\right)$ menghasilkan persamaan: $\mathrm{hf} / \mathrm{E}_{1}=3,7218 \mathrm{Fr}_{2}{ }^{2}-1,5755 \mathrm{Fr}^{2}+0,6953$

\section{Kesimpulan}

Berdasarkan data penelitian serta hasil analisis dan pembahasan, dapat disimpulkan bahwa Reduksi gaya akibat tumbukan baffle blocks terbesar terjadi pada seri L.V (gigi setengah lingkaran, baffle blocks $\mathrm{V}$ ) yaitu sebesar 1,0413 $\mathrm{N}$ dan reduksi gaya terkecil terjadi pada seri L.X (gigi setengah lingkaran, tanpa baffle blocks) yaitu 0,0098 N. Baffle blocks yang paling efektif mereduksi gaya akibat tumbukan adalah tipe V. Dengan debit aliran yang sama dari variasi bentuk gigi dan baffle blocks tidak terjadi perbedaan yang signifikan terhadap reduksi energi. Perbedaan signifikan terjadi antara seri dengan baffle blocks dan tanpa baffle blocks.Angka reynolds terkecil terjadi pada seri L.C (gigi setengah lingkaran, baffle blocks cekung) dengan nilai $\mathrm{Re}=$ 6505,5352 dan angka Reynolds terbesar terjadi pada seri L.X (gigi setengah lingkaran, tanpa baffle blocks) sebesar 7022,4610. Hal ini menunjukan bahwa baffle blocks efektif meredam turbulensi 
dibanding dengan gigi. Baffle blocks yang paling efektif meredam turbulensi adalah tipe cekung. Untuk meredam panjang loncatan air, seri L.C (gigi setengah lingkaran, baffle blocks cekung) dengan nilai bilangan froude sebesar 0,0827, dan bilangan froude terbesar dimiliki seri S.V (gigi segitiga, baffle blocks V) sebesar 0,1092. Efiensi kehilangan energi dalam kaitanya dengan turbulensi berbanding terbalik dengan besarnya debit. Seri L.C (gigi setengah lingkaran, baffle blocks cekung) adalah yang paling efektif, dengan angka unjuk kerja sebesar 4,36\% dan angka korelasi 0,9899. Menghasilkan persamaan hubungan kehilangan energi dan turbulensi $\mathrm{hf} / \mathrm{E}_{1}=0,0015 \mathrm{Re}_{1}^{2}-0,0274 \mathrm{Re}_{1}+0,6703$. Efiensi kehilangan energi dalam kaitannya dengan panjang loncatan terbesar terjadi pada seri L.C (gigi setengah lingkaran, baffle blocks cekung) dengan unjuk kerja 14,52\%, angka korelasi 0,9907, dan menghasilkan persamaan hubungan kehilangan energi dan loncatan air hf/ $\mathrm{E}_{1}=3,7218 \mathrm{Fr}_{2}^{2}-1,5755 \mathrm{Fr}^{2}+0,6953$.

\section{Daftar Pustaka}

Abdurrosyid, Jaji. 2003. Transpor Sedimen. Buku Ajar. Surakarta: FT Teknik Sipil, Universitas Muhammadiyah Surakarta.

Abdurrosyid, J., et.all. 2018. Influence of Baffle Block and Weir Downstream Slope at Stilling Basin of Solid Roller Bucket Type on Hydraulic Jump and Energy Dissipation. AIP Conference Proceedings. 1977 (1), 040031. 26 Juni 2018. ISBN: 978-0-7354-1687-1.

Ackers, P. 1980. Weirs and Flumes for Flow Measurement. London: The Pitman Press.

Anggrahaini. 1997. Hidrolika Saluran Terbuka. Surabaya: CV Citra Media.

Anonim. 1973. Design of Contol Dam. United States Department of the Interior Bureau of Reclamation. Nevada.

Anonim. 1986. Standar Perencanaan Irigasi. Kriteria Perencanaan Bagian Bangunan Utama KP-02. Jakarta: Yayasan Badan Penerbit Pekerjaan Umum.

Anonim. 2014. Module 4 Hydraulic Structures for Flow Diversion and Storage. http://nptel.iitm.ac.in/courses/Webcoursecontents/IIT\%20Kharagpur/Water\%20Resource\%20E ngg/pdf/m4108.pdf, IITM, Kharagpur, Diakses 25 Oktober 2014.

Chow, V.T. 1985. Hidrolika Saluran Terbuka. Jakarta: Erlangga.

Dwi, S.N. 2015. "Pengaruh Penempatan Baffle Blocks Tipe Cekung pada Bendung Dengan Kolam Olak Solid Roller Bucket Terhadap Panjang Loncat Air dan Kehilangan Energi”. Skripsi (tidak diterbitkan). Surakarta: Universitas Muhammadiyah Surakarta.

Mawardi, Erman dkk. 2002. Desai Hidraulik Bendung Tetap. Bandung: Alfabeta.

Mulyo, A. B. 2011. "Pengaruh Variasi Kemiringan pada Hulu Bendung dan Penggunaan Kolam Olak Tipe Solid Roller Bucket Terhadap Loncatan Air dan Gerusan Setempat". Skripsi (tidak diterbitkan). Surakarta: Universitas Negeri Sebelas Maret.

Pembra, J. A. 2013. "Pengaruh Variasi Kemiringan Tubuh Hilir Bendung dan Penempatan Baffle Blocks pada Kolam Olak Tipe Solid Roller Bucket Terhadap Loncatan Hidrolis dan Peredaman Energi." Skripsi (tidak diterbitkan). Surakarta: Universitas Muhammadiyah Surakarta.

Peterka, A. J. 1974. Hydraulics Design Of Stilling Basin And Energy Disipaters. Colorado: United States Department Of Interior, Bureau Of Reclamation. Nevada.

Peturson, G. S. 2013. Model Investigation of a Low Froude Number Roller Bucket at Urridafos HEP. Tesis (tidak diterbitkan). Hjardarhagi: Universitas of Iceland.

Tauvan, A.P. 2009. "Kajian Peredam Energi Pada Kolam Olak Tipe Solid Roller Bucket Dengan Baffle Blocks Bentuk Kotak." Skripsi (tidak diterbitkan). Surakarta: Universitas Muhammadiyah Surakarta.

Triatmodjo, B. 1995. Hidraulika I. Yogyakarta: Beta Offset.

Triatmodjo, B. 1995. Hidraulika II. Yogyakarta: Beta Offset. 